\title{
Mechanisms of Activation of the Classical Pathway of Complement by Hageman Factor Fragment
}

\author{
Berhane Ghebrehiwet, Bruce P. Randazzo, Joseph T. Dunn, \\ Michael Silverberg, and Allen P. Kaplan, Division of Allergy, \\ Rheumatology, and Clinical Immunology, Department of Medicine, State \\ University of New York at Stony Brook, Stony Brook, New York 11794
}

\begin{abstract}
A BSTRACT The mechanism by which a fragment of activated Hageman factor (HFf) activates the classical pathway of complement in serum or platelet-poor plasma has been further delineated. When serum or platelet-poor plasma was incubated with various concentrations of HFf, the total complement hemolytic activity was reduced in a dose-dependent manner. This activation appears to be due to the direct interaction of HFf with macromolecular $\mathrm{Cl}$, since incubation of purified $\mathrm{Cl}$ with $\mathrm{HFf}$ resulted in dissociation of the subunits with concomitant reduction of $\mathrm{Clr}$ antigenicity that is indicative of $\mathrm{Cl}$ activation. HFf-dependent activation was prevented by prior treatment of HFf with the active site-directed inhibitor, H-Dproline-phenylalanine-arginine chloromethyl ketone or with a specific inhibitor of activated HF derived from corn. Incubation of $\mathrm{HFf}$ with highly purified $\mathrm{Cl} r$ also resulted in activation of $\mathrm{Clr}$ as assessed directly using a synthetic substrate or indirectly by activation of $\mathrm{C} 1 \mathrm{~s}$ and consumption of $\mathrm{C} 2$. However, incubation of $\mathrm{HFf}$ with highly purified $\mathrm{Cls}$ resulted in formation of activated $\mathrm{Cls}(\mathrm{Cl} \overline{\mathbf{s}})$ but this was less efficient than HFf activation of $\mathrm{Clr}$. We therefore conclude that activation of $\mathrm{Cl}$ in macromolecular $\mathrm{Cl}$ is the result of HFf conversion of $\mathrm{Cl} r$ to Clir; activation of Cls then occurs primarily by CĪr and to a lesser degree by the direct action of $\mathrm{HFf}$.
\end{abstract}

\section{INTRODUCTION}

The biological significance of the interaction between the proteins of the complement system and the various

This work was presented in part at the Annual Meetings of the Federation of American Societies for Experimental Biology, Atlanta, GA and the American Federation for Clinical Research, San Francisco, CA.

Received for publication 31 March 1982 and in revised form 28 December 1982.
Hageman factor-dependent pathways leading to blood coagulation, fibrinolysis, and kinin formation has been the subject of considerable interest. Both systems are capable of generating mediators of vascular permeability that play a role in certain inflammatory processes. Hageman factor ( $\mathrm{HF}$, coagulation Factor XII) ${ }^{1}$ activates plasma prekallikrein to kallikrein, which in turn cleaves higher molecular weight kininogen to produce bradykinin, a potent mediator of vascular permeability (1). Bradykinin may play a major role in the pathogenesis of hereditary angioedema $(2,3)$. Activation of the complement system on the other hand, leads to the production of a number of biologically active peptides, such as the anaphylatoxins, C3a $(4,5), \mathrm{C} 4 \mathrm{a}(6)$, and C5a (7). The interaction of both systems may thus produce mediators of inflammation and tissue damage. In previous reports $(8,9)$, we have shown that a fragment of activated Hageman factor, HFf, can activate the classical pathway of complement by interacting with macromolecular $\mathrm{Cl}$ and that this activation was both dose and time dependent. In this report we demonstrate that activation by $\mathrm{HFf}$ is enzymatic and does not require the participation of either prekallikrein or plasminogen. Further, we present evidence that $\mathrm{HFf}$ activates macromolecular $\mathrm{Cl}$ by cleavage and activation of $\mathrm{Clr}$ and that it is capable of activating $\mathrm{Clr}$, and to a lesser degree, Cls, in purified systems.

\footnotetext{
${ }^{1}$ Abbreviations used in this paper: CBZ-, benzyloxycarbonyl-; CHFI, corn Hageman factor inhibitor; CMK, H-DPro-Phe-Arg chloromethyl ketone; DFP, disopropyl fluorophosphate; DTNB, 5,5'-dithiobis (2-nitrobenzoic acid); GPS$\mathrm{E}$, guinea pig serum diluted $1 / 50$ in $0.04 \mathrm{M}$ EDTA-GVB; GVB, veronal-buffered saline containing $0.1 \%$ gelatin; $H F$, Hageman factor (coagulation Factor XII); NHS, normal human serum; NHS-E, NHS containing 0.01 M EDTA; PNA, paranitroanilide.
} 


\section{METHODS}

Buffers. The following buffers were used: VB, isotonic veronal-buffered saline, $\mathrm{pH} 7.4 ; \mathrm{VB}^{++}, \mathrm{VB}$ containing 0.15 $\mathrm{mM} \mathrm{CaCl}$ and $0.5 \mathrm{mM} \mathrm{MgCl}_{2} ; \mathrm{GVB}^{++}$containing $0.1 \%$ gelatin; GVB-E, VB containing $0.1 \%$ gelatin and $0.01 \mathrm{M}$ EDTA; $\mathrm{SGVB}^{++}, \mathrm{GVB}^{++}$containing $2.5 \%$ (wt/vol) sucrose; $\mathrm{Mg}-$ EGTA, $0.1 \mathrm{M} \mathrm{MgCl}_{2}, 0.1 \mathrm{M}$ EGTA adjusted to $\mathrm{pH} \mathrm{7.0;} \mathrm{and}$ Mg-GVB, VB containing $0.5 \mathrm{mM} \mathrm{MgCl}_{2}$ and $0.1 \%$ gelatin. Each buffer was prepared according to published procedures (10).

Purified proteins. Macromolecular $\mathrm{Cl}$ was purified according to a procedure described by Gigli et al. (11) except that the serum, containing $1 \mathrm{ml}$ of $2.5 \mathrm{M}$-DFP was first made free of plasminogen by passage over a lysine-Sepharose $6 \mathrm{~B}$ immunoadsorbent column (12) equilibrated with VB pH 7.0, containing $0.15 \mathrm{M} \mathrm{NaCl}, 0.02 \mathrm{M}$ sodium barbital, $0.01 \mathrm{M}$ $\mathrm{MgCl}_{2}, 5 \mathrm{mM} \mathrm{CaCl}$ and $1 \mathrm{ml}$ of $2.5 \mathrm{M}$ diisopropylfluorophosphate. Highly purified Hageman factor (HF), activated Hageman factor ( $\mathrm{HFa})$, and Hageman factor fragment (HFf) were prepared as described (13). Clq (14), Clr (15), C1s (16), C2 (17), C3 (18), and C4 (19) were isolated according to published procedures. The functional activity of the isolated Clq, Clr, and Cls subunits was assessed by their ability to form a functionally active macromolecular $\mathrm{Cl}$. Briefly, $5 \mu \mathrm{g} \mathrm{Clr}, 5 \mu \mathrm{g} \mathrm{Cls}$, and $12 \mu \mathrm{g} \mathrm{Clq}$ were incubated for $15 \mathrm{~min}$ at $30^{\circ} \mathrm{C}$ in the presence of $0.001 \mathrm{M}$ calcium as described by Ziccardi and Cooper (20). The ability of such reconstituted $\mathrm{Cl}$ to form EACl 4 was tested by incubating various dilutions to EAC4 in $\mathrm{SGVB}^{++}\left(15 \mathrm{~min}, 30^{\circ} \mathrm{C}\right)$. The hemolytic activity of the generated EACl4 was then assayed by sequential addition of $\mathrm{C} 2\left(10 \mathrm{~min}, 39^{\circ} \mathrm{C}\right)$ and GPS-EDTA $\left(60 \mathrm{~min}, 37^{\circ} \mathrm{C}\right)$ as described elsewhere $(20)$.

Aggregated IgG. Human IgG that had been isolated from serum by a single step on a column of DEAE Affi-Gel Blue (Bio-Rad Laboratories, Richmond, CA) was aggregated by incubation at $63^{\circ} \mathrm{C}$ for $20 \mathrm{~min}$ at $10 \mathrm{mg} / \mathrm{ml}$ concentration. Particulate aggregates were removed by centrifugation at $200 \mathrm{~g}$ for $5 \mathrm{~min}$. The supernate was used as soluble aggregated IgG.

Protein determination. The protein concentration was determined either by the method of Lowry et al. (21) or, for $\mathrm{Clq}$, by measuring the optical density at $280 \mathrm{nM}$ and using an extinction coefficient $\mathrm{E}_{\mathrm{lcm}}^{\mathrm{is}}$ of 6.8 (14).

Inhibitors of activated $H F$. The active site-directed inhibitor of activated HF, H-D-proline-phenylalanine-arginine chloromethyl ketone (CMK), was a gift from Dr. Elliot Shaw and Dr. Charles Kettner of Brookhaven National Laboratory (Long Island, NY) and Corn Hageman factor inhibitor (CHFI) was a gift from Dr. Yoshio Hojima and Dr. John Pisano of the National Institutes of Health (Bethesda, MD).

Antisera. Monospecific antisera to $\mathrm{Clq}, \mathrm{Clr}$, and $\mathrm{Cls}$, were raised in rabbits and characterized previously (9).

Immunochemical analyses. Radial double immunodiffusion (Ouchterlony) analyses were carried out in $1 \%$ agarose in barbital-buffered saline $\mathrm{pH} 8.6$, containing $0.05 \mathrm{M} \mathrm{NaCl}$ and $0.01 \mathrm{M}$ EDTA. Immunoelectrophoresis was carried out for $2 \mathrm{~h}$ at $4.7 / \mathrm{cm}$ at $4^{\circ} \mathrm{C}$. Electrophoresis in the presence of sodium dodecyl sulfate (SDS PAGE) was performed according to the method of Weber and Osborn (22) using the modifications of Harpel and Mosesson (23).

Preparation of EA, EAC4, and EAC14. The preparation of sheep erythrocytes sensitized with rabbit antibody (EA), and complement-carrying cellular intermediates, EACl, EAC4, and EACl4 were prepared according to established methods (24). Briefly, $5 \mathrm{ml}$ of EA $\left(1 \times 10^{9} \mathrm{ml}\right)$ was incubated with $0.5 \mathrm{ml}$ of $\mathrm{Cl}$ for $15 \mathrm{~min}$ at $37^{\circ} \mathrm{C}$. The cells were washed once with warm $\mathrm{GVB}^{++}$(kept at $30^{\circ} \mathrm{C}$ ) and resuspended to original volume as EACl. Then $1 \mathrm{ml}$ of EACl $\left(1 \times 10^{9} / \mathrm{ml}\right)$ was further incubated with $100 \mu \mathrm{g}$ of isolated and active $\mathrm{C4}$ for $30 \mathrm{~min}$ at $37^{\circ} \mathrm{C}$, washed once with $0.01 \mathrm{M}$ EDTA-GVB, followed by two washes with $\mathrm{GVB}^{++}$and resuspended to original volume in $\mathrm{GVB}^{++}$. EACl4 cells were prepared by further incubation with $\mathrm{Cl}$ as described above (24).

Hemolytic assays. Various concentrations of HFf were tested for their effect on serum complement by incubation with $10 \mu \mathrm{l}$ of normal human serum (NHS) for $60 \mathrm{~min}$ at $37^{\circ} \mathrm{C}$. Then $0.2 \mathrm{ml}$ of sensitized sheep erythrocytes (EA 5 $\times 10^{8} / \mathrm{ml}$ ) were added, the volume was adjusted to $0.4 \mathrm{ml}$ with $\mathrm{GVB}^{++}$, and further incubated for $60 \mathrm{~min}$ at $37^{\circ} \mathrm{C}$. The reaction was stopped by addition of $1 \mathrm{ml}$ of cold $\mathrm{GVB}^{++}$, the mixture was centrifuged, and free hemoglobin was measured in the supernate at $412 \mathrm{nM}$.

Determination of $\mathrm{CH}_{50}$ (25) and individual complement titrations of $\mathrm{Cl}(10)$ and $\mathrm{C4}(24)$ were performed according to previously published methods.

Assay for the activity of HFf. Assays for HFf activity were conducted with a Gilford recording spectrophotometer (Gilford Instrument Laboratories, Inc., Oberlin, $\mathrm{OH}$ ) using an automated cell changer thermostated to $37^{\circ} \mathrm{C}$ as described earlier (13). Semicro plastic cuvettes (Precision Cells, Inc., Hicksville, NY) were used for routine assays of HFf. The reaction mixture consisted of $0.4 \mathrm{ml}$ of $50 \mathrm{mM}$ Tris $/ \mathrm{HCl}$, $\mathrm{pH} 7.8$ containing $0.117 \mathrm{M}$ sodium chloride (to give $\mathrm{I}=0.15$ ) and $500 \mu \mathrm{M} \mathrm{H}-\mathrm{D}-\mathrm{Pro}-\mathrm{Phe}$-Arg-PNA (S2302, paranitroanilide; Kabi Group, Inc., Greenwich, CT).

Treatment of HFf with inhibitors. To determine whether the ability of HFf to activate the classical pathway was dependent upon the availability of its enzymatic site, HFf was first treated $\left(60 \mathrm{~min} 37^{\circ} \mathrm{C}\right.$ ) with either $10 \mu \mathrm{M}$ of the active site-directed CMK (26) or $100 \mu \mathrm{g} / \mathrm{ml}$ of a specific inhibitor obtained from corn (CHFI) (27) as described elsewhere. Such treated or untreated HFf was then incubated with NHS followed by incubation with $0.2 \mathrm{ml} \mathrm{EA}\left(5 \times 10^{8} / \mathrm{ml}\right)$ for 60 min at $37^{\circ} \mathrm{C}$. After centrifugation, the percent hemolysis was determined spectrophotometrically.

Determination of $\mathrm{Clr}$ and $\mathrm{Cls}$ activation by $\mathrm{HFf}$. Highly purified $\mathrm{Clr}(100 \mu \mathrm{g} / \mathrm{ml})$ was incubated with either $10 \mu \mathrm{g} / \mathrm{ml} \mathrm{HFf}$ for $60 \mathrm{~min}$ at $37^{\circ} \mathrm{C}$ in the presence of 0.001 $M$ calcium or with $\mathrm{GVB}^{-}$alone in the presence of $0.01 \mathrm{M}$ EDTA for $15 \mathrm{~min}$ at $37^{\circ} \mathrm{C}$. The ability of such treated $\mathrm{Clr}$ to generate $\mathrm{Cl} \bar{s}$ from $\mathrm{Cls}$ was examined by incubating the mixture with proenzyme $\mathrm{Cls}(100 \mu \mathrm{g} / \mathrm{ml})$ at $37^{\circ} \mathrm{C}$ for 30 $\min$. The conversion of $\mathrm{Cls}$ to $\mathrm{Cl} \bar{s}$ was in turn tested either by the fluid phase destruction of $\mathrm{C} 2$ or $\mathrm{C} 4$ by activated Cls; or the conversion of $\mathrm{Cls}$ to the anodally faster migrating $\mathrm{Cl} \overline{\mathrm{s}}$ on immunoelectrophoresis. In all experiments, untreated proenzyme $\mathrm{Clr}$ (in the presence of $0.001 \mathrm{M}$ calcium) and Cls were included as controls. Alternatively, spectrophotometric assays were conducted at room temperature using a Beckman DU8 spectrophotometer (Beckman Instruments, Inc., Fullerton, CA). The enzyme solution $(5 \mu \mathrm{l})$ was added to $0.4 \mathrm{ml}$ of assay mixture comprising $0.05 \mathrm{M}$ Tris $\mathrm{HCl}, \mathrm{pH}$ 7.8 containing $0.112 \mathrm{M} \mathrm{NaCl}, 2.5 \mathrm{mM} \mathrm{CaCl}_{2}, 0.2 \mathrm{mM}$ CBZL-lysine thiobenzyl ester and $1 \mathrm{mM}$ DTNB (Vega Biochemical, Tucson, AZ). The rate of change of absorbance at 412 $\mathrm{nm}$ was determined and converted to the value of nanomoles substrate cleaved per minute using $\mathrm{E}_{412}=13,600 \mathrm{M}^{-1} \mathrm{~cm}^{-1}$ as described (28). The assay was linear in response to the amount of $\mathrm{Cls}$ offered.

Immunochemical determination of Clr activation in serum. The ability of $\mathrm{HFf}$ to activate $\mathrm{Clr}$ in serum was tested by incubating various concentrations of HFf with NHS-E (normal human serum containing $0.01 \mathrm{M}$ EDTA) at 
$37^{\circ} \mathrm{C}$ for $60 \mathrm{~min}$. The amount of $\mathrm{Clr}$ activated was than analyzed by the single radial immunodiffusion technique (29), as modified by Ziccardi and Cooper (30). The immunodiffusion slides contained appropriate dilutions of monospecific antiserum to $\mathrm{Clr}$ in $1 \%$ agarose in $0.03 \mathrm{M}$ potassium phosphate pH 8.0, containing $0.1 \mathrm{M} \mathrm{NaCl}$ and $0.01 \mathrm{M}$ EDTA. Serum CI-INA readily binds to activated $\mathrm{Cl}(\mathrm{r}(\mathrm{Cl} \overline{\mathrm{r}})$ but not to native $\mathrm{Clr}$, and masks its antigenicity (31). The disappearance of $\mathrm{Clr}$ antigenicity in this assay is therefore a measure of C1r activity and the degree of activation could be quantitated as described (30).

\section{RESULTS}

Effect of HFf on total complement hemolytic activity in normal and deficient plasma. As described in our earlier work $(8,9)$ and confirmed in these studies, incubation of HFf with normal serum results in the sequential depletion of serum $\mathrm{C1}, \mathrm{C} 4, \mathrm{C} 2$, and C3 indicative of activation of the classical pathway of complement. This depletion is reproducible, dose dependent, and is maximal after an incubation period of $60 \mathrm{~min}$ at $37^{\circ} \mathrm{C} \mathrm{(9).} \mathrm{Fig.} 1$ is a representative of five such experiments in which NHS was first incubated with various concentrations of purified HFf for $60 \mathrm{~min}$ at $37^{\circ} \mathrm{C}$, and the residual complement hemolytic activity determined as described in Methods. A concentration of $12 \mu \mathrm{g} / \mathrm{ml} \mathrm{HFf}$ was sufficient to cause the reduction of complement hemolytic activity by $100 \%$, while $2.5 \mu \mathrm{g} / \mathrm{ml}$ of $\mathrm{HFf}$ caused a $36 \%$ reduction. Table I demonstrates the results of comparative studies of the effects of HFf on NHS; citrated, $(0.38 \%)$ plateletpoor, plasminogen-free plasma; prekallikrein-deficient plasma, or Factor XI-deficient plasma and is a

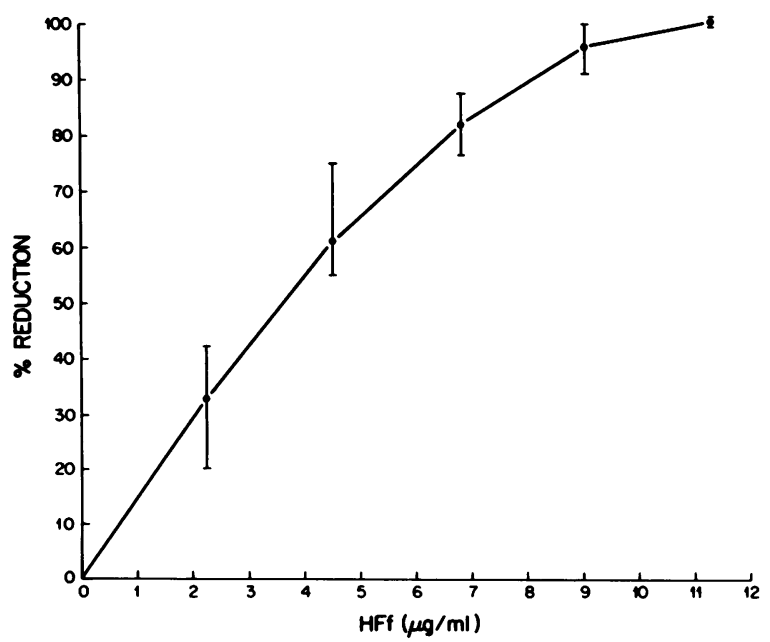

Figure 1 Dose-dependent consumption of complement in serum by HFf. NHS was incubated with various concentrations of HFf. The residual total complement hemolytic activity was determined as described in Methods.
TABLE I

Comparison of Effect of HFf on Serum and Plasma ${ }^{\circ}$

\begin{tabular}{lc}
\hline \multicolumn{1}{c}{ Reaction mixture } & Reduction \\
\hline & $\%$ \\
$\mathrm{NHS}+\mathrm{GVB}^{++}$ & $0-$ \\
$\mathrm{NHS}+\mathrm{HFf}$ & $93 \pm 1.1$ \\
$\mathrm{NHP}+\mathrm{GVB}^{++}$ & $0-$ \\
$\mathrm{NHP}+\mathrm{HFf}$ & $78 \pm 1.5$ \\
Prekall. DP $+\mathrm{GVB}^{++}$ & $0-$ \\
Prekall. DP $+\mathrm{HFf}^{+}$ & $72 \pm 4.3$ \\
Factor XI-DP + GVB & $0-$ \\
Factor XI-DP + HFf & $68 \pm 1.9$ \\
\hline
\end{tabular}

- NHS, citrated, $(0.38 \%)$ platelet-poor, plasminogen-free plasma (NHP) or prekallikrein-deficient platelet-poor plasma (Prekall. DP) or Factor XI-deficient plasma (Factor XI-DP) was incubated with $\mathrm{HFf}(10 \mu \mathrm{g} / \mathrm{ml})$ in the presence of calcium or $\mathrm{GVB}^{++}$for $60 \mathrm{~min}$ at $37^{\circ} \mathrm{C} .10 \mu \mathrm{l}$ of such treated serum or plasma was further incubated with EA. The released hemoglobin was measured in the supernate at $412 \mathrm{~nm}$ as described in Methods. Data represent a mean of three replicate experiments \pm SEM.

mean of three replicate experiments. When the sample sera or plasma were incubated with a high concentration of HFf $(10 \mu \mathrm{g} / \mathrm{ml})$, which produces maximal reduction in complement hemolytic activity (Fig. 1), a reduction of $92-100 \%$ of their total hemolytic activity was observed and was consistent throughout these studies.

Abrogation of the effect of HFf on serum complement by active site-directed inhibitors. To determine whether activation of complement by HFf was an enzymatic event requiring the availability of an active site, $6 \mu \mathrm{g}$ HFf was first incubated with either $10 \mu \mathrm{M}$ of the active site-directed CMK or $100 \mu \mathrm{g} / \mathrm{ml}$ of CHFI. Then a fivefold excess $(0.5 \mu \mathrm{g})$ of such inhibitor-treated or untreated HFf was incubated with $10 \mu \mathrm{l}$ NHS for $60 \mathrm{~min}$ at $37^{\circ} \mathrm{C}$. After further incubation $(60 \mathrm{~min}$ at $37^{\circ} \mathrm{C}$ ) with EAs the amount of hemolysis was determined and as shown in Table II, the ability of HFf to activate complement in serum was totally abrogated by both CMK and CHFI, indicating that the active site of $\mathrm{HFf}$ is required for such activation. Incubation of NHS with either CMK or CHFI alone on the other hand, did not have any effect on its hemolytic activity.

Quantitative analysis of Clr activation. It is known that when $\mathrm{Cl}$ is activated in serum, Ci-inactivator (Cī-INA) readily binds to active $\mathrm{Clr}(\mathrm{Cl} \overline{\mathbf{r}})$ thereby masking its antigenicity (30). A single radial immunodiffusion method has therefore been developed by Ziccardi and Cooper (30) exploiting this interaction. The ability of $\mathrm{HFf}$ to activate $\mathrm{Clr}$ in serum was analyzed by incubating various concentrations of HFf with serum containing $0.01 \mathrm{M}$ EDTA and sub- 
TABLE II

Abrogation of Effect of HFf on Serum Complement by Active Site-directed Inhibitors ${ }^{\circ}$

\begin{tabular}{lc}
\hline \multicolumn{1}{c}{ Reaction mixture } & Reduction \\
\hline & $\%$ \\
NHS + GVB & 0 \\
NHS + HFf & 96 \\
NHS + (HFf + CMK) & 0.9 \\
NHS + (HFf + CHFI) & 1.0 \\
NHS + CMK & 2.0 \\
NHS + CHFI & 0 \\
\hline
\end{tabular}

- HFf was first inactivated by incubation with either the active site-directed $(10 \mu \mathrm{M}) \mathrm{CMK}$ or $100 \mu \mathrm{g} / \mathrm{ml}$ of CHFI. Treated HFf was then incubated with NHS and its activity compared with that of untreated HFf after further incubation with $0.2 \mathrm{ml} \mathrm{EA}\left(5 \times 10^{8}\right)$ $\mathrm{ml})$. Percent hemolysis was determined spectrophotometrically. Data represent a mean of duplicate and reproducible results.

jected to immunodiffusion analysis as described. Fig. 2 demonstrates the dose-dependent reduction in $\mathrm{Clr}$ precipitin ring that is indicative of $\mathrm{Clr}$ activation by HFf. Clr in untreated serum however remained without a change. Table III is a calculated representation of Fig. 2 and shows the residual $\mathrm{Clr}$ antigen (micrograms per milliliter) after incubation with HFf. Untreated Clr was used as control.

Activation of Clr and Cls by HFf. The homogeneity of representative preparations of $\mathrm{Clq}, \mathrm{Clr}$, and $\mathrm{Cls}$ used in these studies are shown in Fig. 3. In order to elucidate the mechanism by which HFf enzymatically initiates the activation of macromolecular $\mathrm{Cl}$, highly purified $\mathrm{Clr}(100 \mu \mathrm{g} / \mathrm{ml})$ was incubated with either $5 \mu \mathrm{g} / \mathrm{ml} \mathrm{HFf}$ for $60 \mathrm{~min}$ or alone in the presence of $0.001 \mathrm{M}$ EDTA for $15 \mathrm{~min}$ at $37^{\circ} \mathrm{C}$. Then the ability of such treated $\mathrm{Cl}$ r to generate activated $\mathrm{Cls}(\mathrm{Cl} \bar{s})$ from Cls was examined by incubating with $100 \mu \mathrm{g} /$ $\mathrm{ml}$ proenzyme $\mathrm{Cls}$ at $37^{\circ} \mathrm{C}$ for $30 \mathrm{~min}$. The conversion

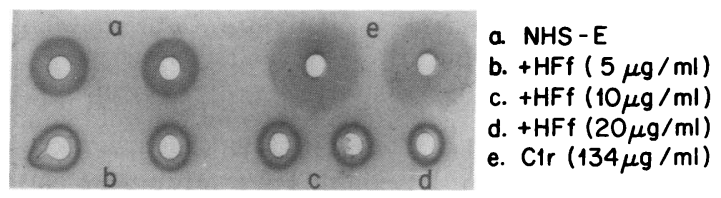

FIgURE 2 Quantitative single radial immunodiff usion analysis. NHS containing $0.01 \mathrm{M}$ EDTA was incubated with or without HFf. Plates contained monospecific antiserum to $\mathrm{Cl} \mathrm{r}$ in $1 \%$ agarose. After staining with Amido Schwartz the sizes of precipitation rings were measured and converted to micrograms per milliliter $\mathrm{Clr}$ remaining. The photo depicts duplicate radial diffusions except for condition "d". The results are tabulated in Table III, and are the mean of duplicate experiments.
TABLE III

Quantitation of Clr Activation by HFf in EDTA Serum ${ }^{\circ}$

\begin{tabular}{lcc}
\hline \multicolumn{1}{c}{ Reaction mixture } & Residual Clr & Activation \\
\hline & $\mu g / m l$ & $\%$ \\
NHS-E $+\mathrm{GVB}^{=}$ & 50 & - \\
$\mathrm{Cl}$ & 134 & - \\
NHS-E $+5 \mu \mathrm{g} / \mathrm{ml} \mathrm{HFf}$ & 36 & 28 \\
NHS-E $+10 \mu \mathrm{g} / \mathrm{ml} \mathrm{HFf}$ & 21 & 58 \\
NHS-E $+20 \mu \mathrm{g} / \mathrm{ml} \mathrm{HFf}$ & 16 & 68 \\
\hline
\end{tabular}

- NHS-containing $0.01 \mathrm{M}$ EDTA was incubated with GVB $^{x}$ with various concentrations of $\mathrm{HFf}$ at $37^{\circ} \mathrm{C}$ for $60 \mathrm{~min}$ and applied to Mancini plates containing monospecific anti-Clr as described in the legend to Fig. 2. Untreated, isolated $\mathrm{Clr}(134 \mu \mathrm{g} / \mathrm{ml})$ was used as control for the specificity of the antibody. Assay was run in duplicate. Each datum is a mean.

of $\mathrm{Cls}$ to $\mathrm{Cl} \bar{s}$ was in turn tested by one of several methods as described in Methods. In all the experiments conducted, it was found that $\mathrm{Cl} r$ was converted into enzymatically active $\mathrm{Clr}(\mathrm{Cl} \overline{\mathrm{r}})$, since such treated $\mathrm{Cl} r$ was capable of activating highly purified Cls. However, untreated $\mathrm{Cl} r$ was not capable of converting $\mathrm{Cls}$ into $\mathrm{Cl} \bar{s}$. Table IV is the result of triplicate experiments in which the fluid phase destruction of $\mathrm{C} 2$ by $\mathrm{Cl} \bar{s}$ was used to detect conversion of $\mathrm{Cls}$ by activated Clr. In addition, a shift in electrophoretic mobility to the region of activated $\mathrm{Clr}$ and $\mathrm{Cls}$ was also observed when $\mathrm{HFf}$ activated-Clr or Cls, activated by

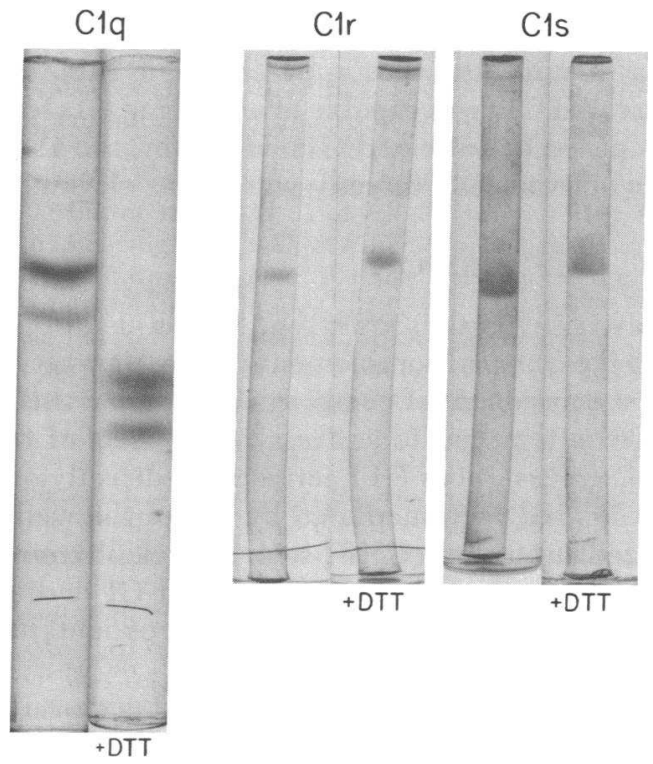

FIGURE 3 SDS-polyacrylamide gel electrophoresis of Clq, $\mathrm{Clr}, \mathrm{Cls}(20 \mu \mathrm{g})$ in the absence and in the presence of 0.014 M DTT. Gels were stained with Coomassie Blue. 
TABLE IV

Demonstration of Activation of Cls by HFf and HFf-treated $\mathrm{Clr}(\mathrm{Clr})^{\circ}$

\begin{tabular}{|c|c|c|}
\hline Reactants & & Hemolysist \\
\hline & & $\%$ \\
\hline $\mathrm{C} 2+$ buffer & +EACl4 & $75 \pm 1.4$ \\
\hline $\mathrm{C} 2+\mathrm{Clr}$ & $+\mathrm{EACl} 4$ & $73 \pm 2.1$ \\
\hline $\mathrm{C} 2+\mathrm{Cls}$ & $+\mathrm{EACl} 4$ & $70 \pm 1.8$ \\
\hline $\mathrm{C} 2+[\mathrm{Cls}+\mathrm{Clr}] \S$ & $+\mathrm{EACl4}$ & $69 \pm 2.1$ \\
\hline $\mathrm{C} 2+[\mathrm{Cls}+\mathrm{Clr}]^{\prime \prime}$ & +EACl4 & $0-$ \\
\hline $\mathrm{C} 2+[\mathrm{Cls}+\mathrm{Clr}+\mathrm{HFf})]$ & +EACl4 & $5-$ \\
\hline $\mathrm{C} 2+[\mathrm{Cls}+\mathrm{HFf}]$ & +EACl4 & $30 \pm 1.5$ \\
\hline
\end{tabular}

- The amount of $\mathrm{C} 2$ which was sufficient to produce $75 \%$ lysis in the absence of $\mathrm{Cl}$ s, was incubated with buffer or with Cls that had been pretreated in various ways as indicated.

$\ddagger$ The values represent percent $\mathrm{C} 2$ hemolytic activity remaining as result of $\mathrm{C} 2$ consumption by $\mathrm{Cl} \bar{s}$.

$\$ \mathrm{Cls}(100 \mu \mathrm{g} / \mathrm{ml})$ incubated at $37^{\circ} \mathrm{C}$ for $30 \mathrm{~min}$ with $\mathrm{Clr}(100$ $\mu \mathrm{g} / \mathrm{ml}$ ), in the presence of $0.001 \mathrm{M}$ calcium, prior to addition to EAC14.

" $\mathrm{Cl} \bar{r}$ was obtained by incubation of proenzyme $\mathrm{Clr}$ at $37^{\circ} \mathrm{C}$ for 15 $\min$ in the presence of $0.001 \mathrm{M}$ EDTA.

I Clr, incubated first with $\mathrm{HFf}$ for $60 \mathrm{~min}$ at $37^{\circ} \mathrm{C}$ in the presence of $\mathrm{Ca}^{++}$then with $\mathrm{Cls}$ for $30 \mathrm{~min}$ at $37^{\circ} \mathrm{C}$ prior to addition to $\mathrm{C} 2$. Each datum is a mean of duplicate experiments \pm SEM.

such a mixture ( $\mathrm{HFf}+\mathrm{Clr}$ ), was subjected to immunoelectrophoretic analysis (not shown). These results were also confirmed by spectrophotometric means in which the ability of $\mathrm{Cl} \overline{\mathrm{r}}$ to convert proenzyme $\mathrm{Cls}$ into CIs was measured by using CBZ-L-lysine thiobenzyl ester as a substrate. It is apparent from Table $\mathrm{V}$ that HFf-treated $\mathrm{Cl} r$ was capable of activating $\mathrm{Cls}$ fourfold as compared to untreated Clr. However, the ability of HFf to activate Cls directly was not as elevated.

\section{DISCUSSION}

We have previously shown that HFf is capable of initiating the classical complement pathway by activating the first component of complement $(8,9)$. In this paper we have attempted to address two aspects of this interaction. First, does HFf activate $\mathrm{Cl}$ directly or is $\mathrm{Cl}$ activation indirect, mediated by one of the well-characterized substrates of HFf such as prekallikrein (32)? Second, if the interaction of HFf and $\mathrm{Cl}$ is direct, is it enzymatic, and which of the subcomponents of complement are involved?

HFf is a weak coagulant enzyme because it lacks the binding site for surfaces that initiate the intrinsic coagulation pathway (33). Thus Hageman factor-dependent activation of Factor XI (34) was not considered to play a role in the activation of $\mathrm{Cl}$. This notion
TABLE V

Demonstration of Activation of Cls by HFf-treated-Clr Using CBZ-L-Lysine Thiobenzyl Ester as Substrate ${ }^{\circ}$

\begin{tabular}{lc}
\hline \multicolumn{1}{c}{ Reactants } & Cls \\
\hline & nmoles $/$ min $/ \mu g$ \\
Cls + buffer & 1.35 \\
Cls + Clr 1 & 1.47 \\
Cls + [Clr + HFf] $]$ & 6.47 \\
Cls + trypsin" & 6.02 \\
Cls + HFf & 2.64 \\
\hline
\end{tabular}

- Cls $(100 \mu \mathrm{g} / \mathrm{ml})$ was incubated with or without pretreated Clr for $30 \mathrm{~min}$ at $37^{\circ} \mathrm{C}$.

I Cls $(100 \mu \mathrm{g} / \mathrm{ml})$ was incubated with $\mathrm{Clr}(100 \mu \mathrm{g} / \mathrm{ml})$ in the presence of $0.001 \mathrm{M} \mathrm{Ca}^{++}$.

$\S \mathrm{Clr}(100 \mu \mathrm{g} / \mathrm{ml})$ preincubated with $5 \mu \mathrm{g} / \mathrm{ml} \mathrm{HFf} 30 \mathrm{~min}$ at $37^{\circ} \mathrm{C}$ in the presence of calcium.

" Cls $(100 \mu \mathrm{g} / \mathrm{ml})$ preincubated with $1 \%$ (wt/wt) trypsin $10 \mathrm{~min}$ at $37^{\circ} \mathrm{C}$. The reaction was stopped by addition of $2 \%(w t / w t)$ soybean trypsin inhibitor.

is further supported by the fact that $\mathrm{HFa}$, the major Factor XI activator (35), does not cause complement activation (9). HFf, however, is a potent prekallikrein activator (36), thus it is possible that kallikrein mediates HFf-dependent $\mathrm{Cl}$ activation. Further, kallikrein has been shown to activate the $\mathrm{Clr}$ and $\mathrm{Cl}$ s subcomponents of complement (37) so there is precedent to consider such an interaction. However, our studies with prekallikrein-deficient plasma (Table I) demonstrate that prekallikrein is not a requirement of complement activation of $\mathrm{HFf}$ and, in fact, $\mathrm{Cl}$ activation in this plasma is indistinguishable from that seen in normal plasma. Plasmin has also been shown to activate $\mathrm{Cls}$ and we considered the possibility that it is involved in HFf-dependent $\mathrm{Cl}$ activation (38). The major activators of plasminogen in Hageman factordependent fibrinolysis are kallikrein $(32,39)$ and Factor XIa $(40,41)$. Yet prekallikrein as well as Factor XI-deficient plasma behave normally (Table I). Furthermore, HFf is a poor Factor XI activator. Thus it is not surprising that HFf activation of $\mathrm{Cl}$ is also normal in plasminogen-free plasma. These data all suggest that HFf might activate $\mathrm{Cl}$ directly and our data support this conclusion. When HFf and purified $\mathrm{Cl}$ are incubated together $\mathrm{Cl}$ becomes activated and can digest $\mathrm{C} 4$ and $\mathrm{C} 2$. That the process is enzymatic and dependent upon the active site of HFf is indicated by the abrogation of $\mathrm{Cl}$ activation when $\mathrm{Hff}$ is incubated with either CMK or CHFI (27).

Since C4 and C2 digestion is a consequence of $\mathrm{Cl}$ activation by HFf, we can conclude that the Cls subcomponent has become activated (17). This could occur either by HFf activation of Cls directly or by 
conversion of $\mathrm{Cl} \mathbf{r}$ to $\mathrm{Cl} \overline{\mathrm{r}}$ and activation of $\mathrm{Cls}$ by $\mathrm{Cl} \overline{\mathbf{r}}$. By single radial immunodiffusion analysis of $\mathrm{Clr}$ in serum $\mathrm{Cl}$, we demonstrated loss of $\mathrm{Cl} r$ antigenicity after incubation with $\mathrm{HFf}$ indicating conversion to $\mathrm{Cl} \overline{\mathrm{r}}$ and complex formation with CI-INA $(27,28)$. We also demonstrate $\mathrm{Clr}$ activation upon incubation of purified Clr with HFf (Table V). However, incubation of $\mathrm{HFf}$ with $\mathrm{Cls}$, in the absence of $\mathrm{Clr}$ also lead to $\mathrm{Cls}$ activation (Tables IV and V). It appears that HFf converts $\mathrm{Clr}$ to $\mathrm{Cl} \overline{\mathrm{r}}$ in macromolecular $\mathrm{Cl}$ and that both HFf and $\mathrm{Cl} \overline{\mathrm{r}}$ may then activate Cls. However, the interaction of $\mathrm{HFf}$ with $\mathrm{Clr}$ appears to be the predominant reaction. It is difficult to quantitate how much $\mathrm{Clr}$ or $\mathrm{Cls}$ is activated from these studies. That such treatment of $\mathrm{Clr}$ or Cls with HFf triggers complement activation however, is quite clear.

The activation of the classical pathway is usually triggered by the ability of Clq to recognize and bind to activating substances such as immune complexes. $\mathrm{Clq}$ is a collagen-like glycoprotein (42), which, together with $\mathrm{Clr}$ and $\mathrm{Cls}$ forms the $\mathrm{Cl}$ macromolecule (43). Since Clq is known to bind to negatively charged molecules (reviewed in 44, 45), it is possible that an interaction between HFf and Clq might facilitate activation of $\mathrm{Clr}$ and/or Cls. Nonetheless, our data indicate that $\mathrm{Clq}$ is not requisite for the reaction to proceed.

Our data may be important in disease states in which simultaneous activation of contact activation and the classical complement pathway is observed such as endotoxic shock (46) or gout (47). It may also be of particular importance in hereditary angioedema. In this disorder, there is evidence of activation of both cascades $(48,49)$ and the absence of CI-INA, the major control protein of activated Hageman factor $(50,51)$ might facilitate conversion of HFa to HFf and thereby perpetuate kinin formation as well as complement activation.

\section{ACKNOWLEDGMENTS}

We wish to thank Ms. Cathy Morency for skillful technical assistance, and Mrs. Karen Abramowski for typing this manuscript.

This investigation was supported in part by grant 5ROl HL23714-02 from the National Heart, Lung, and Blood Institute, grant P50Al 166337-02 from the National Institute of Allergy and Infectious Disease, and the H.O.R. Foundation.

\section{REFERENCES}

1. Kaplan, A. P. 1981. Initiation of the intrinsic coagulation and fibrinolytic pathways of man: the role of surface, Hageman factor, prekallikrein, high molecular weight kininogen and factor XI. Prog. Hemostasis Thromb. 4: 127-175.
2. Curd, J. G., M. Yelvington, M. Burridge, N. P. Stimler, C. Gerard, L. J. Prograis, Jr., C. G. Cochrane, and H. J. Müller-Eberhard. 1981. Generation of bradykinin during incubation of hereditary angioedema plasma. IXth International Complement Workshop, Key Biscayne, FL.

3. Fields, T. R., B. Ghebrehiwet, and A. P. Kaplan. 1982. Is bradykinin responsible for the pathogenesis of hereditary angioedema? Clin. Res. 30: 348a. (Abstr.)

4. Dias da Silva, W., J. W. Eisele, and I. H. Lepow. 1967. Complement as a mediator of inflammation III. Purification of the activity with anaphylatoxin properties generated by interaction of the first four components of complement and its identification as a cleavage product of C3. J. Exp. Med. 126: 1027-1048.

5. Bokisch, V. A., H. J. Müller-Eberhard, and C. G. Cochrane. 1969. Isolation of a fragment (C3a) of the third component of human complement containing anaphylatoxin and chemotactic activity and description of an anaphylatoxin inactivator of human serum. J. Exp. Med. 129: 1109-1130.

6. Gorski, J. P., T. E. Hugli, and H. J. Müller-Eberhard. 1979. C4a: the third anaphylatoxin of the human complement system. Proc. Natl. Acad. Sci. USA. 76: 52995302.

7. Cochrane, C. G., and H. J. Müller-Eberhard. 1968. The derivation of two distinct anaphylatoxin activities from the third and fifth components of human complement. J. Exp. Med. 127: 37i-386.

8. Ghebrehiwet, B., M. Silverberg, and A. P. Kaplan. 1981 Activation of human complement by Hageman factor fragment. Clin. Res. 29: 528a. (Abstr.)

9. Ghebrehiwet, B., M. Silverberg, and A. P. Kaplan. 1981. Activation of the classical pathway of complement by Hageman factor fragment. J. Exp. Med. 153: 665-676.

10. Borsos, T., and H. J. Rapp. 1963. Chromatographic separation of the first component of complement and its assay on a molecular basis. J. Immunol. 9: 851-858.

11. Gigli, I., R. R. Porter, and R. B. Sim. 1976. The unactivated form of the first component of human complement, Cl. Biochem. J. 157: 541-548.

12. Deutsch, D. G., and E. T. Mertz. 1970. Plasminogen: purification of human plasma by affinity chromatography. Science (Wash. DC). 170: 1095-1096.

13. Silverberg, M., J. T. Dunn, L. A. Garen, and A. P. Kaplan, 1980. Autoactivation of human Hageman factor: demonstration utilizing a synthetic substrate. J. Biol. Chem. 225: 7281-7286

14. Kolb, W. K., L. M. Kolb, and E. R. Podack. 1979. Clq: isolation from human serum in high yield by affinity chromatography and development of a highly sensitive hemolytic assay. J. Immunol. 122: 2103-2111.

15. Valet, G., and N. R. Cooper. 1974. Isolation and characterization of the proenzyme form of the Clr subunit of the first complement component. J. Immunol. 112: $1667-1673$.

16. Valet, G., and N. R. Cooper. 1974. Isolation and characterization of the proenzyme form of the Cls subunit of the first complement component. J. Immunol. 112: 339-350.

17. Polley, M. J., and H. J. Müller-Eberhard. 1968. The second component of human complement: its isolation, fragmentation by esterase and incorporation into C3 convertase. J. Exp. Med. 128: 533-551.

18. Tack, B. F., and J. W. Prahl. 1976. Third component of complement: purification from plasma and physiochemical characterization. Biochemistry. 15: 4513-4521. 
19. Müller-Eberhard, H. J., and C. E. Biro. 1963. Isolation and description of the fourth component of human complement. J. Exp. Med. 118: 447.

20. Ziccardi, R. J., and N. R. Cooper. 1976. Physicochemical and functional characterization of the $\mathrm{Cl}$ r subunit of the first complement component. J. Immunol. 116: 496-503.

21. Lowry, O. H., H. J. Rosebrough, A. L. Farr, and R. J. Randall. 1951. Protein measurement with the Folin phenol reagent. J. Biol. Chem. 193: 265-275.

22. Weber, K., and M. Osborn. 1969. The reliability of molecular weight determinations by dodecyl sulfate-polyacrylamide gel electrophoresis. J. Biol. Chem. 244: 4406-4412.

23. Harpel, P. C., and M. W. Mosesson. 1973. Degradation of human fibrinogen by plasma $\alpha_{2}$-macroglobulin-enzyme complexes. J. Clin. Invest. 52: 2175-2184.

24. Cooper, N. R., and H. J. Müller-Eberhard. 1968. A comparison of methods for the molecular quantitation of the fourth component of human complement. Immunochemistry. 5: 155-169.

25. Mayer, M. M. 1967. In Experimental Immunochemistry. E. A. Kabat and M. M. Mayer, editors. Charles C Thomas, Springfield, IL. 133.

26. Silverberg, M., and A. P. Kaplan. 1982. Enzymatic activities of activated and zymogen forms of human Hageman factor (Factor XII). Blood. 60: 64-70.

27. Hojima, Y., J. V. Pierce, and J. J. Pisano. 1980. Hageman factor fragment inhibitor in corn seeds: purification and characterization. Thromb. Res. 20: 149-162.

28. Green, G. D. J., and E. Shaw. 1979. Thiobenzyl benzyloxycarbonyl-L-lysinate, substrate for a sensitive colorimetric assay for trypsin-like enzymes. Anal. Biochem. 93: 223-226.

29. Mancini, G. A., A. O. Carbonara, and J. F. Heremans. 1965. Immunochemical quantitation of antigens by single radial immunodiffusion. Immunochemistry. 2: 235254.

30. Ziccardi, R. J., and N. R. Cooper. 1980. Development of an immunochemical test to assess $\mathrm{CI}$ inactivator function in human serum and its use for the diagnosis of hereditary angioedema. Clin. Immunol. Immunopathol. 15: 465-471.

31. Ziccardi, R. J., and N. R. Cooper. 1978. Demonstration and quantitation of activation of the first component of complement in human serum. J. Exp. Med. 147: 385395.

32. Mandle, R., and A. P. Kaplan. 1977. Human plasma prekallikrein: mechanism of activation by Hageman factor and participation in Hageman factor dependent fibrinolysis. J. Biol. Chem. 252: 6097-6104.

33. Revak, S. D., and C. G. Cochrane. 1976. The relationship of structure and function in human Hageman factor. The association of enzymatic and binding activities with separate regions of the molecule. J. Clin. Invest. 57: 852-860.

34. Heck, L. W., and A. P. Kaplan. 1974. Substrates of human Hageman factor I. Isolation and characterization of PTA (Factor XI) and its inhibition by $\alpha 1$ antitrypsin. J. Exp. Med. 140: 1615-1630.

35. Kaplan, A. P., and K. F. Austen. 1971. A prealbumin activator of prekallikrein II. Derivation of activators of prekallikrein from active Hageman factor by digestion with plasmin. J. Exp. Med. 133: 696-712.

36. Kaplan, A. P., and K. F. Austen. 1970. A prealbumin activator of prekallikrein. J. Immunol. 105: 802-811.

37. Cooper, N. R., L. A. Miles, and J. H. Griffin. 1980. Effects of plasma kallikrein and plasmin on the first component of complement. J. Immunol. 124: 1517.

38. Ratnoff, O. D., and G. B. Naff. 1961. The conversion of $\mathrm{Cls}$ to $\mathrm{Cl}$ esterase by plasmin and trypsin. J. Exp. Med. 125: $337-358$.

39. Colman, R. W. 1969. Activation of plasminogen by human plasma kallikrein. Biochem. Biophys. Res. Commun. 351: 273-279.

40. Mandle, R. H., Jr., and A. P. Kaplan. 1979. Hageman factor-dependent fibrinolysis: generation of fibrinolytic activity by the interaction of human activated factor XI and plasminogen. Blood. 54: 850-862.

41. Saito, H. 1980. The participation of plasma thromboplastin antecedent (Factor XI) in contact-activated fibrinolysis. Proc. Soc. Exp. Biol. Med. 104: 153-157.

42. Calcott, M. A., and H. J. Müller-Eberhard. 1972. Clq protein of human complement. Biochemistry. 11 : 34433450.

43. Lepow, I. H., G. B. Naff, E. W. Todd, J. Pensky, and C. F. Hinz. 1963. Chromatographic resolution of the first component of human complement into three activities. J. Exp. Med. 117: 983-1008.

44. Müller-Eberhard, H. J. 1978. Complement: molecular mechanisms, regulation and biologic functions. In Molecular Basis of Biological Degradative Processes. R. Berlin, H. Hermann, I. Lepow, and J. Tanzer, editors. Academic Press, Inc., New York. p. 65-114.

45. Porter, R. R., and K. M. B. Reid. 1979. Activation of the complement system by antibody-antigen complexes: the classical pathway. In Advances in Protein Chemistry. Academic Press, Inc., New York. 33: 1-71.

46. Mason, J. W., U. Kleeberg, and P. Dolan. 1970. Plasma kallikrein and Hageman factor in gram-negative bacteremia. Ann. Intern. Med. 73: 545.

47. Ginsberg, M. H., B. Jaques, C. G. Cochrane, and J. H. Griffin. 1980. Urate crystal-dependent cleavage of Hageman factor in human plasma and synovial fluid. J. Lab. Clin. Med. 95: 497-506.

48. Austen, K. F., and A. L. Sheffer. 1965. Detection of hereditary angioneurotic edema by demonstration of a reduction in the second component of human complement. N. Engl. J. Med. 272: 649-656.

49. Gigli, I., A. P. Kaplan, and K. F. Austen. 1971. Modulation of function of the activated first component of complement by a fragment derived from serum. I. Effect of early components of complement. J. Exp. Med. 134: 1466-1484

50. Forbes, C. O., J. Pensky, and O. D. Ratnoff. 1970. Inhibition of activated Hageman factor and activated plasma thromboplastin antecedent by purified CI inactivator. J. Lab. Clin. Med. 76: 809-815.

51. Schreiber, A. D., A. P. Kaplan, and K. F. Austen. 1973. Inhibition by Cİ INH of Hageman factor fragment activation of coagulation, fibrinolysis, and kinin-generation. J. Clin. Invest. 52: 1402-1409. 